\title{
Characterization of an iridovirus detected from cultured turbot Scophthalmus maximus in Korea
}

\author{
Wi-Sik Kim, Myung-Joo Oh, Sung-Ju Jung, Young-Jin Kim, Shin-Ichi Kitamura*
}

Department of Aqualife Medicine, Yosu National University, San 96-1 Dunduk-dong, Yosu 550-749, South Korea

\begin{abstract}
Juvenile turbot Scophthalmus maximus that became sick during an outbreak of disease at mariculture facilities at Go-Chang, Korea, in 2003, were examined to identify the cause of the disease. The fish had pale body color, an enlarged abdomen, protruding eyes, an enlarged spleen and kidney, and pale gills and/or liver. Histopathogical examination revealed basophilic enlarged cells in the kidney, spleen, gills, heart, stomach, intestine, liver, pancreas and skin. Hexagonal viral particles with a diameter of 136 to $159 \mathrm{~nm}$ were observed in the enlarged cells. A specific 1299 bp fragment of the major capsid protein (MCP) gene of the turbot iridovirus (TBIV) was amplified by PCR. Sequence homology was greater than $93.76 \%$ between the MCP gene in TBIV and the same gene in 5 viruses in the tentatively proposed genus Tropivirus (family Iridoviridae): red sea bream iridovirus, sea bass iridovirus, grouper sleepy disease iridovirus, African lampeye iridovirus and dwarf gourami iridovirus. These results suggest that the virus detected from turbot is similar to the proposed genus Tropivirus.
\end{abstract}

KEY WORDS: Turbot $\cdot$ Scophthalmus maximus $\cdot$ Iridovirus $\cdot$ RSIV $\cdot$ MCP $\cdot$ Tropivirus

Resale or republication not permitted without written consent of the publisher

\section{INTRODUCTION}

Turbot Scophthalmus maximus is a commercially important fish species that occurs mainly in the eastern North Atlantic and the Mediterranean Sea. Catches have declined markedly during the last decade, and as a result aquaculture has become an important source of turbot in several countries, including Spain, France, Norway and China.

In Korea, more than 245000 tons of marine fishes and shellfish were cultured in 2001 (based on the official statistics issued by the National Fisheries Research \& Development Institute in 2003), but the aquaculture industry is now facing difficulties due to over-production and the importation of live fishes. To overcome these problems, fish farmers have switched to more economical species, and turbot was selected because it is fast-growing and in high demand due to the popularity of white meat fish in Korea.

In 2003, an outbreak of disease at aquaculture farms in Go-Chang on the west coast of Korea caused a high rate of mortality (50 to $70 \%$ ) in cultured juvenile turbot. During histopathological examination of the diseased fish, enlarged cells were observed in various internal tissues, which is suggestive of red sea bream iridovirus (RSIV) disease; this also occurs in red sea bream Pagrus major, grouper Epinephelus ocellata (L.), striped beakperch Oplegnathus fasciatus and red drum Sciaenos ocellata (L.) (Jung et al. 1997, Jung \& Oh 2000, Sano et al. 2002, Weng et al. 2002). In addition, a partial iridovirus genome has been detected in the spleens and kidneys of diseased turbot using PCR described by Kurita et al. (1998). In this paper, we report the histopathological characteristics, electron microscopic features and molecular characters of the virus detected in the diseased turbot.

\section{MATERIALS AND METHODS}

Epizootics. Turbot eggs were imported from France and hatched at an aquaculture farm in Go-Chang, 
Korea. Juvenile turbot (mean weight $9.0 \pm 1.9 \mathrm{~g}$, mean length $7.9 \pm 0.5 \mathrm{~cm}$ ) began to show signs of disease in June 2003. Affected fish were lethargic and had a reduced appetite, pale body color, enlarged abdomen and protruding eyes. The key internal characteristics of the diseased fish were an extremely enlarged spleen and kidney, and pale gills and/or liver (Fig. 1).

The fish farmers misdiagnosed the disease as hirame rhabdovirus (HRV) disease or viral hemorrhagic septicemia (VHS) disease, and increased the water temperature from $17-18^{\circ} \mathrm{C}$ to $20-23^{\circ} \mathrm{C}$ in an attempt to control the disease. The mortality increased rapidly when the water temperature was increased. Total mortality was about 50 to $70 \%$. After sampling some of the diseased turbot, the remaining fish were killed, and all facilities were disinfected with sodium hypochlorite.

Histology. The kidney, spleen, gills, heart, stomach, intestine, liver, pancreas, skin, eye and brain were removed from diseased fish and immediately fixed in $10 \%$ neutral buffered formalin (NBF). After fixation, standard histological procedures were used for tissue dehydration and paraffin embedding. Tissue sections were stained with haematoxylin and eosin (H\&E).

Electron microscopy. The spleens were fixed in $2.5 \%$ glutaraldehyde in $0.1 \mathrm{M}$ phosphate buffer $(\mathrm{pH} 7.2)$ at $4^{\circ} \mathrm{C}$. After several rinses with $0.1 \mathrm{M}$ phosphate buffer, each sample was post-fixed with $1 \%$ $\mathrm{OsO}_{4}$ for $1 \mathrm{~h}$. Subsequently, the tissue was dehydrated in an ethanol series and embedded in Epon 812. Ultra thin sections were prepared using an RMC-MTX ultramicrotome (SIMS). Sections were stained with lead citrate and uranyl acetate. Stained grids were observed under a Hitachi-7000 electron microscope.

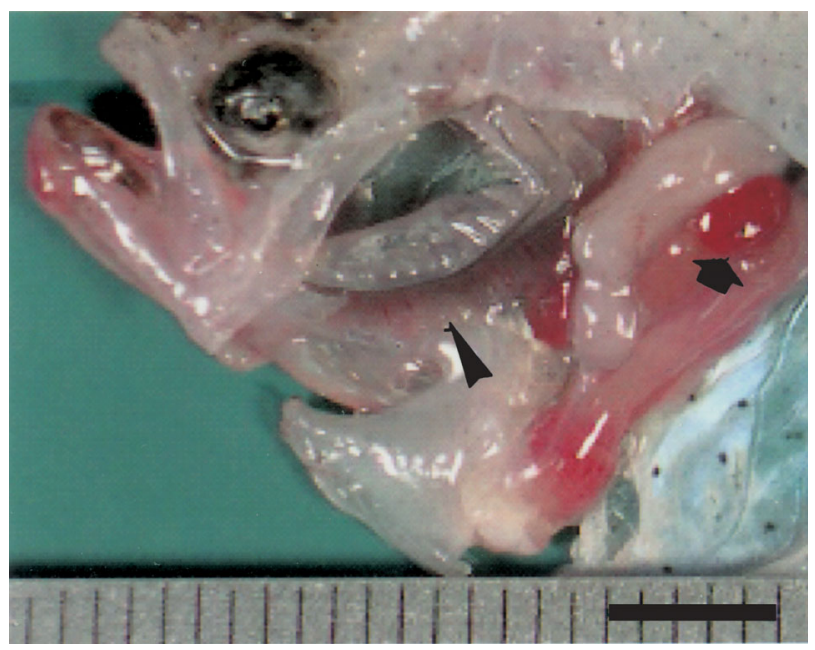

Fig. 1. Scophthalmus maximus. Diseased turbot with a severely enlarged spleen (arrow) and pale gills (arrowhead). Scale bar $=5 \mathrm{~mm}$
DNA extraction. In preliminary investigations, the thick PCR product appeared from spleen and gills samples, although a thin band was amplified from some organs including stomach, intestine, liver and kidney. Therefore, the spleen and gills of diseased turbot were chosen for DNA extraction in this study. These tissues were homogenized in a 4 -fold volume of TE buffer (10 mM Tris-HCl, 1 mM EDTA, $\mathrm{pH}$ 8.0) and centrifuged at $2500 \times \mathrm{g}$ for $10 \mathrm{~min}$ at $4^{\circ} \mathrm{C}$. A $20 \mu \mathrm{l}$ aliquot of Proteinase K (1 mg/ml; TaKaRa) was added to $200 \mu \mathrm{l}$ of the supernatant. The mixture was incubated at $55^{\circ} \mathrm{C}$ for $2 \mathrm{~h}$. DNA was isolated using phenol and chloroform. Nucleic acids were precipitated with isopropanol, resuspended with distilled water and stored at $-20^{\circ} \mathrm{C}$ until use.

PCR amplification. The PCR primer set of the major capsid protein (MCP) gene was designed from the sequence of red sea bream iridovirus MCP gene in the GenBank DNA database (accession number AY310918). The primer position in the deposited MCP gene is as follows: the forward primer (TBIVMCP-1F) is at bases 12 through 30 (5'-CTCAGGTGCGAACGTAACC $-3^{\prime}$ ) and the reverse primer (TBIVMCP-1R) is at bases 1288 through 1310 (5'-TTGACTGCAATAACGACCAGTTC-3'). This primer set covers 1299/1376 bp $(94.4 \%)$ of the MCP gene. The PCR reactions were performed in a final volume of $20 \mu \mathrm{l}$ of reaction mixture containing $50 \mathrm{mM} \mathrm{KCl}, 10 \mathrm{mM}$ Tris- $\mathrm{HCl}$ ( $\mathrm{pH}$ 9.0), $1.5 \mathrm{mM} \mathrm{MgCl}_{2}, 0.1 \%$ Triton X-100, $100 \mathrm{pM}$ of each primer, $0.2 \mathrm{mM}$ of each dNTP, $1 \mathrm{U}$ Taq DNA polymerase and template DNA. PCR amplification was performed using a GeneAmp 2400 thermal cycler (Perkin Elmer) with 30 cycles $\left(95^{\circ} \mathrm{C}\right.$ for $1 \mathrm{~min}, 59^{\circ} \mathrm{C}$ for $1 \mathrm{~min}$, and $72^{\circ} \mathrm{C}$ for $1 \mathrm{~min}$ ). The PCR products were analyzed in $1.5 \%$ agarose gels containing ethidium bromide and visualized under UV light.

Cloning of the PCR product and sequencing. The 1299 bp specific PCR product was purified using the QIAquick Gel Extraction Kit (Qiagen). The purified PCR product was cloned into the PCR 2.1 vector system (Invitrogen), and then transformed to Escherichia coli strain TOP10 (Invitrogen) using standard protocols. The vector was extracted from grown E. coli TOP10 and used for sequencing.

Sequencing was performed based on the dideoxynucleotide termination method in an automated ABI PRISM 310 DNA sequencer (PE Biosystems) using the ABI PRISM Big Dye Terminator Cycle Sequencing FS Ready Reaction Kit (PE Biosystems) and the M-13 forward and reverse universal primer set. To obtain complete sequencing data, another primer set was designed in the inserted gene and used for sequencing. The sequence of this primer set was as follows: TBIVMCP-2F (5'-CTGGTCTCCGGTATCACCA-3') and TBIVMCP-2R (5'-TGACGGGATGACTGAACCT- 
$\left.3^{\prime}\right)$. Analysis of the results was performed using Genetyx Win Ver. 5.1 software. The nucleotide sequence of the partial MCP gene of turbot iridovirus (TBIV) was submitted to GenBank (accession number AB166788).

The TBIV MCP gene was compared with the MCP genes of 2 genera of iridoviruses - (1) genus Lymphocyctivirus (lymphocystis disease virus 1 [LCDV-1; L63545, Tidona \& Darai 1997]), (2) genus Ranavirus (grouper iridovirus [GIV; AF364593, Murali et al. 2002] and frog virus 3 [FV3; U36913, Mao et al. 1996]), and the genus Tropivirus, tentatively proposed by Sudthongkong et al. (2002) (red sea bream iridovirus [RSIV; AY310918, Sudthongkong et al. 2002], sea bass iridovirus [SBIV; AB109372, Sudthongkong et al. 2002], dwarf gourami iridovirus [DGIV; AY285744, Sudthongkong et al. 2002], grouper sleepy disease iridovirus [GSDIV; AY285746, Sudthongkong et al. 2002] and African lampeye iridovirus [ALIV; AY285745, Sudthongkong et al. 2002]).

\section{RESULTS}

\section{Histopatholgy and electron microscopy}

All moribund fish had enlarged cells in the kidney, spleen, gills, heart, stomach, intestine, liver, pancreas and skin. The enlarged cells had an extremely basophilic and granular cytoplasm, and their nuclei were often hypertrophic, fragmented or not visible.

In the spleen, large numbers of enlarged cells appeared mainly in the splenic pulp and sheathed tissue accompanied by hemorrhages (Fig. 2A). The kidney had enlarged cells in the glomerulus (Fig. 2B) and haematopoietic tissue together with necrosis and infiltration of inflammatory cells. The tubular epithelium of the kidney occasionally showed degeneration. In the gills, many enlarged cells were found in the branchial arteries, venous sinus and inter-lamellar epithelia of the filaments. The filaments showed necrosis in the inter-lamellar epithelia and hyperemia in the lamellar capillaries. In the skin, many enlarged cells were located adjacent to adipose tissue, and infiltration of inflammatory cells occurred around the adipose tissue and muscle fibers. In the heart, enlarged cells occurred in the bulbus arteriosus, atrium, ventricles and bulbus endocardium (Fig. 2C). The epicardium was infiltrated by inflammatory cells. In some fish, necrosis was observed in the myocardium. In the stomach, the lamina propria, submucosa, muscle layer and serous membrane contained enlarged cells and inflammatory cells (Fig. 2D). Some fish also had enlarged cells in the epithelial layer. In the intestine, numerous enlarged cells occurred in the lamina propria and submucosa but not in the muscle layer. Inflammatory cells and necrosis were observed in the lamina propria and submucosa. In the liver, enlarged cells and inflammatory cells were observed in the sinusoids and adjacent parenchymal cells, where multiple discrete necrotic foci were observed. In the pancreas, enlarged cells occurred adjacent to the acinar cells, and necrosis was visible in the acinar cells. In the eyes, inflammatory cells and necrosis appeared in the choroid, but enlarged cells were not observed. The brain showed no histopathological changes. No histopathological changes including enlarged cells were observed in the any control tissues (Fig. 2E,F).

Electron microscopy revealed many hexagonalshaped virions in the enlarged cells and necrotic area. Each virion consisted of a central, electron-dense core surrounded by an electron-translucent zone, and measured 136 to $159 \mathrm{~nm}$ from vertex to vertex (the size was calculated by measuring 50 virions) (Fig. 3).

\section{PCR amplification}

The results of PCR using the TBIVMCP-1F and TBIVMCP-1R primer set are shown in Fig. 4. The specific PCR products corresponding to the 1299-bp fragment of the MCP gene were detected in the spleen and gills, and the negative control using distilled water showed no amplification.

\section{Analysis of the MCP nucleotide sequence}

The homology of the MCP gene between TBIV and other reported iridoviruses is shown in Table 1. The nucleotide sequence of TBIV MCP was highly homologous with viruses in the tentatively proposed genus Tropivirus (SBIV, 94.38\%; RSIV, 94.30\%; GSDIV, $94.23 \%$; ALIV, $93.92 \%$; and DGIV, $93.76 \%$ ). When the deduced amino acid sequences were compared, the homology between TBIV and the genus Tropivirus was more than $97.92 \%$ (data not shown). On the other hand, the homology between TBIV and the other 2 genera was less than $56.35 \%$ for nucleotide sequences and less than $49.2 \%$ for deduced amino acid sequences.

\section{DISCUSSION}

We observed enlarged cells in various tissues during histopathological observations and many hexagonal virions (136 to $159 \mathrm{~nm}$ ) in the enlarged cells and necrotic areas. The histopathological signs and virion size are similar to those of red sea bream iridovirus (RSIV) disease in red sea bream (Inouye et al. 1992) 

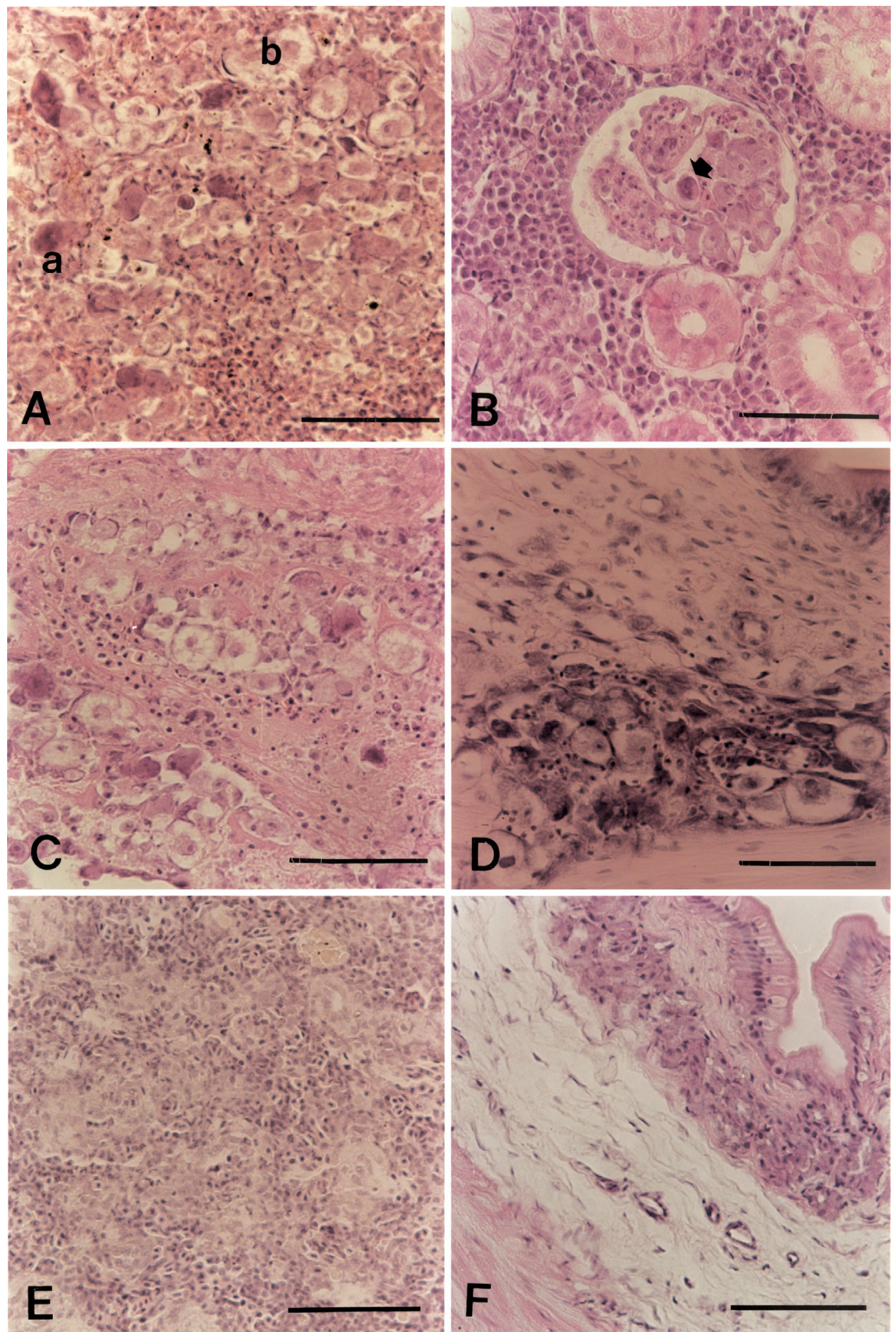

Fig. 2. Scophthalmus maximus. Histopathology of turbot infected with the turbot iridovirus (TBIV). (A) Many enlarged cells with an extremely basophilic (a) and granular cytoplasm (b) in the spleen. (B) Enlarged cell in the glomerulus of the kidney (arrow). (C) Necrosis and many enlarged cells in the bulbus endocardium of the heart. (D) Many enlarged cells in the submucosal layer of the stomach. (E) Spleen and (F) stomach of control tissue. Scale bars $=50 \mu \mathrm{m}$ 


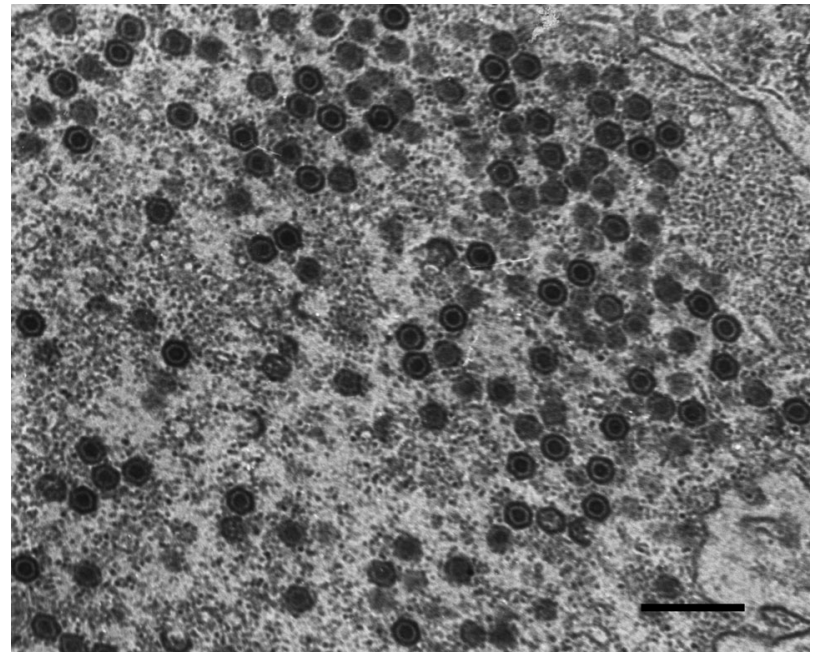

Fig. 3. Iridovirus particles of infected turbot ranging from 136 to $159 \mathrm{~nm}$ in the cytoplasm of enlarged cells. Scale bar $=$ $500 \mathrm{~nm}$

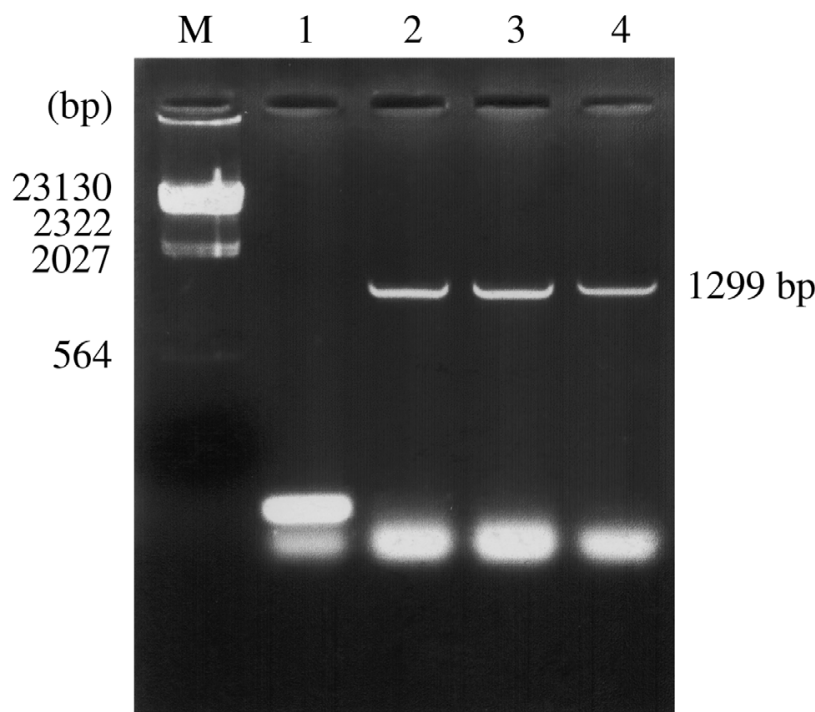

Fig. 4. Detection of TBIV MCP gene from the gills and spleen of diseased turbot by PCR. Lanes are M: molecular marker; 1: negative control without template; 2: gills of diseased turbot; 3 : spleen of diseased turbot; 4: positive control (red sea bream iridovirus, RSIV)

Table 1. Comparative analysis (\%) of the MCP nucleotide sequence between TBIV and other iridoviruses

\begin{tabular}{|c|c|c|c|c|c|c|c|c|}
\hline TBIV & SBIV & RSIV & GSDIV & ALIV & DGIV & FV3 & GIV & LCDV-1 \\
\hline TBIV & 94.38 & 94.3 & 94.23 & 93.92 & 93.76 & 56.35 & 52.06 & 53.06 \\
\hline SBIV & & 99.3 & 99.85 & 94.84 & 94.84 & 56.44 & 51.35 & 54.08 \\
\hline RSIV & & & 99.31 & 95.07 & 95.07 & 56.62 & 51.65 & 53.7 \\
\hline GSDIV & & & & 94.84 & 94.84 & 56.36 & 51.28 & 54 \\
\hline ALIV & & & & & 99.62 & 57.1 & 51.95 & 53.02 \\
\hline DGIV & & & & & & 56.88 & 51.8 & 52.95 \\
\hline FV3 & & & & & & & 69.83 & 52.18 \\
\hline GIV & & & & & & & & 54.67 \\
\hline LCDV-1 & & & & & & & & \\
\hline
\end{tabular}

and striped beakperch (Jung \& Oh 2000). Also, turbot iridovirus (TBIV) induced $60 \%$ of turbot mortality at $23^{\circ} \mathrm{C}$ in experimental infection, although no mortality was observed in the non-injection group (W. S. Kim, M. J. Oh, S. T. Jung, S. I. Kitamura unpubl. data). This result suggests that the mass mortality of turbot was caused by this virus.

The outbreak of TBIV disease in Go-Chang in 2003 occurred at 17 to $18^{\circ} \mathrm{C}$, and the mortality increased rapidly when the water temperature was increased to $20-23^{\circ} \mathrm{C}$. The optimum temperature for maintaining turbot is around $17^{\circ} \mathrm{C}$, and a temperature of 20 to $23^{\circ} \mathrm{C}$ may cause stress in these fish. We suspect that the increased temperature triggered an increase in mortality. Examination of how temperature affects the physiological condition of turbot and TBIV replication is needed.

Bloch \& Larsen (1993) reported the occurrence of an iridovirus-like agent in cultured turbot fry in Denmark. This agent measured 160 to $185 \mathrm{~nm}$ in diameter and was detected in the fin, gills, liver, kidney, spleen, heart, pancreas, and intestinal collagen. Clinical signs included abnormal movements, spasm swimming and darkened pigmentation in the tail and fins. However, enlarged cells were not observed in any diseased turbot tissues reported by Bloch \& Larsen (1993). TBIVinfected fish showed no specific signs in their fins, and the main signs were pale body color, an enlarged abdomen and protruding eyes. These findings suggest that TBIV is different from the iridovirus-like agent reported by Bloch \& Larsen (1993).

The family Iridoviridae comprises 4 genera: Iridovirus, Chloriridovirus, Ranavirus and Lymphocystivirus (Williams et al. 2000), and RSIV belongs to the genus Ranavirus (The Universal Virus Database of the International Committee on Taxonomy of Viruses). Recently, Sudthongkong et al. (2002) proposed a new genus, Tropivirus, in this family for tropical iridoviruses including RSIV, SBIV, GSDIV, ALIV and DGIV based on nucleotide sequencing of the MCP and ATPase genes. We found that sequence homology in the MCP gene of TBIV was high (>93.75\%) with the MCP genes of these viruses and low with the MCP genes of the genera Ranavirus (FV3; $56.35 \%$ ， GIV; $52.06 \%$ ) and Lymphocystivirus (LCDV-1; $53.06 \%$ ), suggesting that TBIV is similar to the tentatively proposed genus Tropivirus.

RSIV-like viruses have been detected from many fish species in several Asian countries, including Korea, Japan, China, Thailand and Indonesia. Kawakami \& Nakajima 
(2002) reported that RSIV-like disease occurred in 31 cultured fish species including the Perciformes, Pleuronectiformes and Tetraodontiformes; however, this is the first report in turbot. It is unclear whether TBIV was introduced to Korea through imported eggs or whether it is an endemic virus. However, similar viruses have been detected in Korea, and this disease has not been reported in Europe, including France from where the eggs were imported, which suggests that the infection occurred in Korea.

In conclusion, we observed enlarged cells in various turbot tissues and many hexagonal virions (136 to $159 \mathrm{~nm}$ ) in the enlarged cells and necrotic areas that resembled RSIV. The sequence analysis of TBIV MCP suggests this virus is similar to the tentatively proposed genus, Tropivirus, in the family Iridoviridae.

Acknowledgements. We thank Dr. John Bower, Hokkaido University, for his critical review of this manuscript.

\section{LITERATURE CITED}

Bloch B, Larsen JL (1993) An iridovirus-like agent associated with systemic infection in cultured turbot Scophthalmus maximus fry in Denmark. Dis Aquat Org 15:235-240

Inouye $\mathrm{K}$, Yamano K, Maeno Y, Nakajima K, Matsuoka M, Wada Y, Sorimachi M (1992) Iridovirus infection of cultured red sea bream, Pagrus major. Gyobyo Kenkyu 27(1): $19-27$

Jung SJ, Oh MJ (2000) Iridovirus-like infection associated with high mortalities of striped beakperch, Oplegnathus fasciatus (Temminck et Schlegel), in southern coastal areas of the Korean peninsula. J. Fish Dis 23:223-226

Jung SJ, Miyazaki T, Miyata M, Danayadol Y, Tanaka S

Editorial responsibility: Jo-Ann Leong,

Kaneohe, Hawaii, USA
(1997) Pathogenicity of iridovirus from Japan and Thailand for the red sea bream Pagrus major in Japan, and histopathology of experimentally infected fish. Fish Sci 63(5):735-740

Kawakami H, Nakajima K (2002) Cultured fish species affected by red sea bream iridoviral disease from 1996 to 2000. Fish Pathol 37(1):45-47

Kurita J, Nakajima K, Hirono I, Aoki T (1998) Polymerase chain reaction (PCR) amplification of DNA of red sea bream iridovirus (RSIV). Fish Pathol 33(1):17-23

Mao J, Tham TN, Gentry GA, Aubertin A, Chinchar VG (1996) Cloning, sequence analysis, and expression of the major capsid protein of the iridovirus frog virus 3. Virology 216:431-436

Murali S, Wu MF, Guo IC, Chen SC, Yang HW, Chang CY (2002) Molecular characterization and pathogenicity of a grouper iridovirus (GIV) isolated from yellow grouper, Epinephelus awoara (Temminck and Schlegel). J Fish Dis 25:91-100

Sano M, Minagawa M, Nakajima K (2002) Multiplication of red sea bream iridovirus (RSIV) in the experimentally infected grouper Epinephelus malabaricus. Fish Pathol 37(4):163-168

Sudthongkong C, Miyata M, Miyazaki T (2002) Viral DNA sequences of genes encoding the ATPase and the major capsid protein of tropical iridovirus isolates which are pathogenic to fishes in Japan, South China Sea and southeast Asian countries. Arch Virol 147:2089-2109

Tidona CA, Darai G (1997) The complete DNA sequence of lymphocystis disease virus. Virology 230:207-216

Weng SP, Wang YQ, He JG, Deng M, Lu L, Guan HJ, Liu YJ, Chan SM (2002) Outbreaks of an iridovirus in red drum, Sciaenops ocellata (L.), cultured in southern China. J Fish Dis 25:681-685

Williams T, Chinchar G, Darai G, Hyatt A, Kalmakoff J, Seligy V (2000) Family Iridoviridae. In: Van Regenmortel MHV, Fauquest CM, Bishop DHL, Carstens EB and 7 others (eds) Virus taxonomy. Academic Press, San Diego, CA, p 167-182

Submitted: June 14, 2004; Accepted: December 16, 2004 Proofs received from author(s): April 4, 2005 